kann feststellen, dass auch hier der musikalische Ton herrscht. Durch den Vergleich des Kanuri mit den genannten Sprachen sind wir imstande, das Verbalschema des Kanuri und seinen auffallenden Affixwechsel zu erklären, denn es lassen sich im Dazzaga (Sprache der Dazza) drei Schichten von Verbalschemen feststellen, die wohl drei verschiedenen Sprachperioden entsprechen, und von denen die älteste im Kanuri nur mehr in der dritten Person erhalten ist. Neben dieser Sprachgruppe wollen wir die zahlreichen Dialekte der Kotoko südlich des Tschadsees anführen, und wir können schon heute feststellen, dass die Sprache der Yidenna, oder wie sie mit einem Kanuriausdruck heissen, Buduma, mit der Sprache jener eine Gruppe bildet. Dass sich diese Gruppe nach dem Süden erstreckt ist wahrscheinlich, dass sie sich aber vor dem Eindringen der nördlichen Kanuri-Tubu-Gruppe nach Westen erstreckt hat, ist sicher. Denn die vor den Kanuri in Bornu ansässigen Sau gehörten dieser Gruppe an, wie Barth und Nachtigal feststellen konnten. Es wird nun die Aufgabe sein, zu sehen, wie weit sich die Gruppe nach Westen erstreckt hat und ob durch die vom Norden kommenden Einwanderer nicht ein Keil in die Sprachengruppe getrieben worden ist.

Maiduguri ist für den Linguisten ein hochinteressanter Punkt. Es beherbergt zahlreiche Stämme aus der Umgebung, die wegen der besseren Handelsbedingungen aus den Bergen des Südens oder aus dem Osten herbeikommen, und sich in geschlossenen Gruppen in Yerua, der vom Europäerviertel eine halbe Stunde entfernten Eingeborenenstadt, ansiedeln. Aus dem Osten kommen die Banana, die eine ganze Kolonie bilden und als Arbeiter sehr geschätzt sind, und auch die scheuen Gwoza kommen aus dem Südosten der Provinz, um ihre Holzlasten hier zu verkaufen. Aus dem Süden sieht man die Margi und Mandara, aus dem Westen die Bade und Ngizzem, und aus dem Norden zahlreiche Arabaer und Berberstämme, auch hastige Tuda, die ihre Datteln verkaufen und schnell wieder umkehren, da sie das ihnen unzukömmliche Klima Bornos fliehen, in dem sie die verbreiteten Blattern erbarmungslos dahinraffen.

J. Lukas.

\title{
The Linguistic Situation in the Western Parts of the Niger Delta.
}

I write as the colleague of the Rev. J. W. Welch, and as one who, in the middle of other work, is investigating the language and origins of the Isoko people. These people, together with the Urhobos, occupy a tract of country with whose geography I am fairly familiar, viz. that part of the delta of the Niger lying between Abo and Warri. I was therefore much interested in Dr. P. Amaury Talbot's communication in Africa (vI, iii, pp. 33 I and 332).

The use of the sobriquet 'Igabo' when referring to the Isoko should be abandoned. This is a term of contempt used by the Ibo-speaking people of the upper parts of the Niger delta (commonly known as the Kwale-Ibo) when referring to the Isoko; it is difficult to state the exact meaning of the word, suffice it to say that it is very opprobrious. The Ijo of the Forcados 
river and its creeks similarly refer to both Urhobo and Isoko as 'Biotu', a word meaning, so I am informed, 'people of the interior' or 'savages'.

When referring to the Urhobo and Isoko languages, Dr. Talbot points out that Sobo and Isoko are two dialects of a branch of the Edo language. To refer to these languages as 'dialects' does not, in my opinion, appear to be a correct use of the word 'dialect'. It is certainly true that both these languages form part of the Benin family of languages, and are no doubt derived from an ancient form of Bini; but this does not justify their being called dialects. We do not refer to Spanish and Italian as dialects because they are derived from Latin. Occasionally Isoko is regarded as a dialect of Urhobo. There is some justification for this, as the two languages are very similar and possess many words in common; but it is doubtful whether it is allowable so to regard Isoko, seeing that although there are striking similarities between the two languages, there are equally striking differences. For instance, nasalized vowels are fairly common in Urhobo, very rare in Isoko. Some words which are common to both languages may have different meanings in each, e.g. oyoma means 'good' in Urhobo, and 'bad' in Isoko.

Cannot some better word than Edo or Ado be found to describe the Benin family of languages and peoples? I am informed that it is the Ibo word for Benin. If this is so, it is equally as foreign a word as Benin, and not so well known. If, therefore, a foreign word is to be used, Benin is to be preferred. Should a native word be required to describe these peoples and languages, I would suggest the word ' $A k a$ ', which is the Isoko and also, I believe, the Urhobo word for Benin.

From Dr. Talbot's first paragraph I gather that he is of opinion that the Isoko have been known to Europeans for some hundreds of years. If this is his opinion, I am afraid that I cannot agree with him. The very fact that until quite recently they have been known by the objectionable nickname of Igabo, is sufficient proof that they have only been known by hearsay, and by reports spread by their neighbours the Kwale-Ibo. The Isoko say that the first European to come to their country was a man they knew as Oyibo-opia (lit. white-man machette), who was in charge of a trading station at Ase (itself an Ibo town); one old Isoko whom I know, was in his young days a house-boy to Oyibo-opia; I presume therefore that he must have been at Ase so to 60 years ago, probably about the time when the Royal Niger Company obtained its charter. There are also traditions of another European known as 'Taega" (? Tiger) who was engaged in fighting near Uduovori on the Forcados River.

Very tentatively, and subject to perhaps drastic alteration as knowledge increases, I would classify the languages of the Western delta of the Niger under four heads :

r. Ibo type.

Kwale-Ibo, usually known to the people as Abo; this is similar to Onitsha Ibo. 
2. Benin or Aka type.

a. Urhobo and its dialects, e.g. Agbadu, Ughele; $b$. Isoko and its dialects, e.g. Igbide, Owe; $c$. a group of three languages which seem to be most nearly related to ancient Bini : i. Erohwa, spoken by a small clan near Patani, who also speak Isoko as a second language; ii. Evro, spoken by the town of Eferun and its villages; iii. Okpe, spoken by the Okpe people north of Warri. Both ii and iii speak Uthobo as a second language.

3. Yoruba type (or ?Aka type).

Ishekiri.

4. Ijo type.

Western Ijo and its dialects, e.g. Tirakiri, Kabowei.

(Communicated by the REv. J. W. HubBard, M.A., B.Sc., F.R.G.S.)

\section{Payment of Dowry in Fingoland.}

I was present at a native kraal in Fingoland Transkei, South Africa, where dowry (lobola) cattle had arrived. The following statement about the payment of dowry was made to me by an aged Fingo man, the head of the kraal:

'Men have arrived bringing dowry to this kraal, they wish to marry one of our girls. On their arrival they drove four cattle into our cattle-fold. We set apart for them a hut in which to abide and we supplied them with food. It would be customary for these men to bring with them "u-Swazi" (a switch) wherewith to drive the cattle. [That is to say, to make the cattle acceptable in the eyes of those to whom they are to be driven.] In ancient times the "Swazi "was usually an assegai but it might be a clay pot or some such article-a gift to show that the payers of dowry were in earnest in the matter of marriage. If the "Swazi" were accepted by those to whom the dowry had been tendered, that clinched the bond between the houses. Nowadays the "Swazi" which people expect to be brought with dowry is a bottle of brandy. This makes people talk nicely to each other.

' These people having brought dowry and having been provided with food and lodging remain in the place set apart for them. We do not know them [this is figurative] nor have we any dealings with them. We do not know the business upon which they have come. There are three men, so we send three girls to occupy with them for the night the hut which has been set apart. The bride to be is one of the girls and the husband to be is one of the men.

"Those men know that if they "damage" our girls they will be made to pay a fine of cattle, so they take every precaution to see that no harm is done.

"In the very early morning our girls "return to their places", and we send a "Kwedini" (a young lad) to ask the men who have brought the cattle what is their business at this kraal and we say that they should come and talk to us.

'The men come and sit down near the cattle kraal where we meet them 